\title{
WTO and Pakistan: Opportunities and Policy Challenges
}

\author{
ZAFAR MAHMOOD
}

\section{INTRODUCTION}

From its inception the GATT had guided international trade most successfully until the early 1970s. However, afterwards the developed countries (DCs) increasingly recurred to new forms of trade restrictions not covered by the GATT rules. Ironically, these "grey measures" were mostly against the less developed countries (LDCs). These measures constrained international trade exactly at the time when the LDCs started penetrating developed markets. One of the main objectives of the Uruguay Round (UR) accord was to restrict the surge of protectionism.

The accord was the most ambitious and detailed trade accord of all the GATT rounds. It established the World Trade Organisation (WTO).

Before the UR accord the discrimination in textiles, clothing and agriculture was severe because tariffs and non-tariff barriers (NTBs) were employed in such a way that the overall effect of protection accumulated. The Round had agreed upon the harmonisation and reduction of tariffs, and elimination of NTBs (in stages) and thus it is expected that the effective protection will diminish in the DCs. The new accord has ensured multilateral rules for these sectors. All members expected that protection would be eventually lower with full implementation of the accord. In order to protect the interest of different groups the WTO has now lay down nondiscriminatory trading rules for services and trade-related aspects of intellectual property rights (TRIPs), thus covering all major fields of international trade policy.

The new accord offers a variety of new opportunities for Pakistan to expand its export base and diversify its export markets. The most rewarding opportunities for Pakistan are likely to come with trade liberalisation in the world markets in those products where it enjoys a comparative advantage. However, Pakistan will face difficulties, when the DCs will translate their commitments made in the accord into concrete trading opportunities. In fact, some of the agreements leave a margin of interpretation that could allow the reintroduction of protectionist measures by the DCs.

It is against this background that the present paper examines the opportunities and identifies policy challenges resulting from the new trade regime led by the WTO. Islamabad.

Zafar Mahmood is Chief of Research, Pakistan Institute of Development Economics, 


\section{OPPORTUNITIES}

While signing the WTO Agreement members committed to reduce trade barriers, discipline the use of subsidies, countervailing measures, and technical barriers; tighten antidumping rules; eliminate certain restrictive trade-related investment measures; regulate the use of restrictive safeguard actions; strengthen and clarify procedures for the settlement of trade disputes among members; and increase the transparency of national policies. The DCs, in particular, pledged to pursue more liberal trade policies so that imposing protection against the LDCs' exports will now be more difficult than it would have been otherwise. They agreed to provide special dispensations for the LDCs to give them enough time to adjust to the post-UR realities.

With the implementation of the agreement Pakistan's major exports would receive significant tariff reduction from the DCs and the LDCs. Tariffs facing basic manufactures in the LDCs such as textiles and clothing will decline by 8.9 percent, agricultural products by 5.1 percent, minerals and fuels by 13.3 percent and miscellaneous manufactures by 7.5 percent. On the other hand, in the DCs, tariffs on basic manufactures are expected to reduce by 2.2 percent making the export weighted average post-Round tariff as 6.5 percent. In other major exports such as agriculture and miscellaneous manufactures, tariffs are expected to decline by 3.6 percent and 2.5 percent respectively. Thus, the average post-Round tariffs for these products are likely to be 3.4 percent and 10.8 percent, respectively. As a result, Pakistan's total merchandise exports to the DCs and LDCs will benefit from a weighted average tariff reduction of 2.4 percent and 6.9 percent, respectively. Consequently, Pakistani exports will face a weighted average post-Round tariff of 6.9 percent in DCs' markets and 9.1 percent in LDCs' markets [See Khan and Mahmood (1996) and Ingco and Winters (1995)].

\section{Agreement on Textile and Clothing}

The Multi-Fibre Arrangement (MFA) is an international arrangement to manage textile and clothing trade. It is this mechanism which has not only locked export opportunities for the LDCs but also delayed industrial adjustments in the DCs. Ironically, the MFA only restrict exports from selected LDCs, including Pakistan, and not across the DCs [See Jones (1993)]. The MFA is clearly discriminatory and thereby openly violates the basic principle of the WTO. Pakistan's textile and clothing exports are largely directed towards quota countries, particularly the high value added products whose quota utilisation rates are very high (See Table 1). This suggests that the MFA is a binding constraint on Pakistan's high value added textiles. Thus, Pakistan should benefit greatly from the eventual removal of the MFA in 2005. 
Table 1

Pakistan: Direction of Exports to the Quota and the Non-quota Countries

\begin{tabular}{lccc}
\hline Good & Non-quota Countries & Quota Countries & Quota Utilisation \\
\hline Yarn & 95 & 5 & 99.40 \\
Fabrics & 72 & 28 & 99.80 \\
Made-ups & 29 & 71 & 98.10 \\
\hline
\end{tabular}

Source: Ingco and Winters (1995).

An important change brought about by the Agreement on textile and clothing (ATC) is the reduction of NTBs, particularly due to dismantling of the MFA progressively in phases. Since removal of complete MFA will take place at the end of 2004, immediate effects of trade liberalisation on this account will not be very significant. Low and Yeats (1994) show that the proportion of Pakistan's exports affected by existing NTBs should fall from about 60 percent in 1992 to 8 percent as a result of the implementation of the Agreement.

The changes in Pakistan's quota on textile and clothing exports under the normal growth rates without the ATC and with the ATC suggest that between 1994 to 2004 without the ATC, the normal increase in textile quota will be 48.8 percent in the EU, 82 percent in the US, and 89.9 percent in Canada. However, as a result of the ATC these growth rates will rise to 79.2 percent, 139.7 percent, and 155.6 percent, respectively. In the case of clothing, Pakistan's quota would have grown normally without the ATC by 70.8 percent in the EU, 87.7 percent in the US, and 82.6 percent in Canada. On the other hand, under the ATC, these growth rates will be 118.5 percent, 150.0 percent, and 143.5 percent, respectively. In sum, for both textiles and clothing, Pakistan will have additional market access with the elimination of MFA to about 62 percent and 67 percent respectively [See Khan and Mahmood (1996)].

Ingco and Winters (1995) estimate that Pakistan may gain more than US\$ 500 million (on a 1992 base and in 1992 prices) from the abolition of the MFA (See Table 2). This would represent a lower bound since it does not account for the tightness with which the MFA binds Pakistan. Allowing for this Pakistan's gains might get as high as US\$ 1-1.3 billion.

Table 2

Gains from Trade Liberalisation

\begin{tabular}{lccc}
\hline Textiles & Textiles & Agriculture & Agriculture \\
\hline Scenario-1 & Scenario-2 & Scenario-1 & Scenario-2 \\
500 & 1300 & 27.2 & 43.0 \\
\hline Source: Ingco and Winters (1995) & & &
\end{tabular}

Source: Ingco and Winters (1995). 


\section{Agreement on Agricultural Commodities}

This agreement has undoubtedly created conditions that will restrain further growth in agricultural protectionism. Consequently, it is expected that Pakistan's agricultural commodities would become competitive in international markets, provided prevailing domestic policies which discriminate against the agriculture sector are modified according to the requirements of the agreement.

As a result of the implementation of the agreement Ingco and Winters (1995) predict that for Pakistan's major agricultural imports' real prices (relative to prices of manufacturing exports from OECD) are expected to rise by 3.8 percent in wheat, 2.3 percent in coarse grains and 1.8 percent in sugar, while it is expected that price of rice will decline by 0.9 percent and cotton by 1.2 percent in 2002. There will be welfare losses for Pakistan due to agricultural trade liberalisation. However, these losses will be offset by potential efficiency gains from improved resource allocation due to removal of policy distortions. These losses will be further reduced provided Pakistan diversify its agricultural exports by exporting spices, vegetables, fruits, flowers, and plants, where the DCs have agreed to drastically reduce tariffs. However, a fuller exploitation of Pakistan's export potential for these commodities would require considerable improvement in the areas of storage, transportation, and especially packaging which must conform to international standards [See Azhar (1995)].

In net terms, the implementation of reforms in agriculture sector is predicted to result in net gain for Pakistan of about US\$ 27.2 million (in 1992 prices). The estimated gains increase to US\$ 43 million if potential induced investment and increasing returns in the sector are also taken into account (See Table 2).

\section{General Agreement on Trade in Services (GATS)}

The GATS has extended multilateral rules to a number of tradable services. The first round of negotiations has achieved limited liberalisation, however, it has opened the door for further liberalisation in future. Participation in the GATS provides Pakistan an opportunity to increase the economic efficiency of its services sector, ${ }^{1}$ greater access to lower cost/higher quality service inputs, and increased market access for its own competitive service exports, such as construction services and professional services. With a vast majority of low wage skilled labour, service is an area that provides vast potential growth to Pakistan. Pakistan can gain by specialising and exploiting the newly granted market access, and by attracting foreign investment in the services sector. For Pakistan a competitive and efficient services sector would create income directly and would stimulate competitiveness elsewhere in the economy.

${ }^{1}$ Efficiency in the services sector will improve through increased competition, transfer of technology, or expansion of resources, in particular physical and human capital. 
Pakistan is likely to benefit from Article IV on LDCs' participation, which is aimed at promoting their interest by specific commitments made by the members, referring explicitly to the provision of technology "on a commercial basis, to access to distribution channels and information networks" and to sectors of "export interest" to the LDCs. The DCs are required to establish contact points through which countries like Pakistan can seek technical assistance in the areas of the services sector.

Pakistan participated in the GATS negotiations, but did not undertake extensive commitments. Out of a possible 620 commitments, Pakistan made 108 commitments, with 27.8 percent of commitment with no market access limitation and 35.2 percent commitments with no national treatment limitation.

\section{Agreement on Trade-related Investment Measures (TRIMs)}

The TRIMs agreement prohibits a number of conditions which governments often impose on foreign investments to encourage investment in accordance with national priorities. Pakistan's compliance with the TRIMs agreement establishes the incentive for increased foreign investment by demonstrating that the country is committed to provide stable and predictable environment by upholding international trade rules.

Pakistan attracts foreign investment by extending many attractive incentives to foreigners, however, it has been using some TRIMs to induce multinational enterprises to meet a minimum level of performance criteria ${ }^{2}$ For instance, Pakistan maintains links between certain tariff exemptions and local content requirement ${ }^{3}$ in a number of sectors. Pakistan has made commitments to eliminate measures, which restrict foreign investment by 2000. With the removal of restrictions on foreign investment, Pakistan may be successful in attracting more foreign investment.

\section{Agreement on Trade-related Intellectual Property Rights (TRIPs)}

The TRIPS agreement provides for increased surveillance of national property protection laws. Implementation of the laws increases demand for royalty payments and restrictions on the transfer of technology. Accordingly, the TRIPs' implementation would require significant reforms of the intellectual property regime in Pakistan. There are dynamic gains that Pakistan can make, provided owners of intellectual property receive effective protection of their property in the country. In the immediate run Pakistan's commitment to fulfil its TRIPs requirements would send a clear and powerful signal to foreign investors that the country is committed to attracting and protecting their intellectual property. Consequently, the increased

${ }^{2}$ TRIMs in Pakistan include local content requirements, procurement procedures and export performance requirements.

${ }^{3}$ Interestingly, this requirement is equivalent to a Rule of Origin that specifies a certain domestic content for the product to be considered of home origin [Falvey and Reed (1998)]. 
supply of foreign knowledge and technology under the TRIPs environment should stimulate the domestic R\&D activities and ultimately promote the technology-led development in the country.

\section{Dispute Settlement}

The provisions on "dispute settlement" is a welcome addition to the trade policy instruments, as it would strengthen non-discrimination among trading partners, make world trade more predictable and transparent, and reduce the scope for unilateral action by the DCs. Nevertheless, the dispute settlement system is marked by certain serious limitations, such as delayed relief, and the process is often very costly and even the delayed relief may prove to be totally, illusory in certain cases. It is mainly due to the lack of a mechanism for enforcing a decision at the WTO.

\section{POLICY CHALLENGES}

Pakistan is facing growing competition in the international market as restructuring is taking place through out the world. Ironically, in all those areas that offer a greater scope of trade expansion to Pakistan are the ones where so far the access to the DCs markets and the concessions granted by the DCs have been minimal. Thus, the prospects of economic growth for Pakistan before the full implementation of the agreement are not very bright. In the following we discuss challenges that different sectors of Pakistan are facing in the global arena.

\section{Textiles and Clothing}

The implementation of commitments under the ATC by the DCs is an important issue for Pakistan. So far tariffs on textiles and clothing remain high in the DCs. In fact, the agreement-phasing rules have allowed the quota countries to delay the bulk of such transfers towards the end of the phasing-out period. Contrary to Pakistan's expectations the experience of the past four years has been disappointing. Virtually, no items previously under quota had been included in the first integration phase, while the integration programme of more (quota) sensitive products in each category has been postponed. 4 The postponing tactics employed by the DCs have violated the spirit of a gradual phasing-in of the products covered by the ATC. In fact, the political economy of textile protectionism in the DCs is such that the interest groups opposed to liberalisation are propagating that trade with poor countries will produce more poor at home. Such fears have inhibited the adjustment process in the DCs' markets. This is, in turn, providing them an excuse to delay the agreed trade liheralisation. In fact the rhanoe in the Rules of Orioin annlied to textiles and

${ }^{4}$ The latest projections suggest that most of the liberalisation is concentrated at the end of the 10 -year period [See Bender (1997)]. This implies that Pakistan needs to plan to climb the quota cliff on the first day of 2005. 
clothing is a clear indication in this regard, which has now started disrupting trade in textiles and clothing. The Rules of Origin are not used in accordance with the provisions of the ATC. Similarly, the use of the safeguard provisions of the ATC is excessive. In the phasing-out period Pakistani exporters will have a greater responsibility to prevent illegal efforts to divert their exports through third countries using false labelling of origin.

The MFA also permits exports from countries and firms that are not internationally competitive. With its phasing-out a very competitive export market will emerge. However, market access will not be automatic. The extent of actual market availability will depend on how Pakistani exporters take advantage of the new opportunities. That is, unless Pakistan competes in cost and quality with competitors, it might not be able to maintain, let alone increase, share in the global market. It is worth noting that the MFA quota currently protects some of the inefficient firms in Pakistan, they will be wiped out once the MFA is no longer there.

The opening up of Eastern Europe is likely to adversely affect the transfer of export capabilities from EU to the developing Asia. Since 1989, the offshore production of the DCs has been shifting fast from Asia to Eastern Europe. East European countries benefit from skilled and relatively low wage labour as well as from a long tradition in textiles (particularly, the Czech and Slovak Republics and Hungary). Geographical proximity provides an added advantage to these countries. The EU investors are now concentrating the production of high quality and complex made-up textiles and clothing in Eastern Europe. Production in Asia is now increasingly limited to simpler products, like casual wear or other goods for sale on local markets. For Pakistan to enter into higher-end products, it would have to ensure appropriate training to textile and clothing workers and stable enforceable contracts with foreign investors.

With trade liberalisation in textiles and clothing in Pakistan, which is reciprocally demanded by the DCs, it is expected that the import bill will rise because of the demise of some local industries, as importing becomes more profitable than producing in the country. However, if local industry restructures itself in an efficient manner, then the negative impact will be lesser.

\section{Agriculture}

So far the Agreement on Agricultural Commodities has done little to actually liberalise trade. This is because the way the tariffication exercise was undertaken countries inflated tariff equivalent calculations in such a way that they are more than compensated for the measures they were replacing, and ensured that the tariff reductions required under the Agreement have little effect on the actual level of protection [Low (1995)]. In fact, major DCs have been able to transform their restrictive agricultural regimes into extremely high levels of tariff protection, much higher than those that the LDCs can maintain under the agreement. 
Reduction in wheat subsidy by exporting nations would mean a higher import bill for Pakistan - a net importer of wheat. Although the Singapore Ministerial Conference has pledged to compensate the net food importing LDCs from negative effects, once commercial agricultural imports find their applications, Pakistan could end up experiencing a net negative effect, if it does not remove domestic policy distortions.

The prospects of Pakistan getting a share of the rice markets in Southeast Asia are rather remote because the variety of glutinous rice popular there is not produced in Pakistan. Besides, quality consideration may also prevent Pakistan in gaining market share in this region. Thus, the opening up of the rice markets in Indonesia, Japan, and Republic of Korea is unlikely to create any major new opportunities for Pakistan.

The Agreements on Sanitary and Phytosanitary (SPS) Measures encourage the use of Codex Standards. In their use the SPS measures will be operating like other trade barriers. With the Agreement becoming a reality, Pakistan will have to cover a lot of ground to adjust itself to such international standards in order to capture the new opportunities in agricultural commodities.

\section{Services}

The liberalisation of trade in services can bring gains for Pakistani economy provided the issues most important to Pakistan (e.g. temporary movement of unskilled and semi-skilled workers) are ultimately included in the GATS. While analysing the commitments made by the members Hoekman (1995) notes that market access commitments by the DCs in labour-intensive services (which require temporary movement of workers) are more restrictive. Most of these commitments are still subject to the 'economic needs' which inhibits the movement of natural persons from the LDCs, like Pakistan. Pakistan's primary challenge in this regard is to actively participate in future WTO negotiations to ensure that its own agenda is ultimately incorporated into the Agreement.

The biggest challenge facing Pakistan in trade in services is the obligation to open its own services sector to foreign competition. This challenge is particularly acute in financial services wherein Pakistan has undertaken a number of specific commitments regarding foreign participation and national treatment. However, Pakistan has filed MFN exemptions in banking and other financial services. Pakistan has also made a limited offer in telecommunications. However, in future Pakistan will have to open up services sector to foreigners. For the future Pakistan needs to frame rules and regulations for the services sector which conform to the WTO rules.

\section{TRIMs}

As committed Pakistan will have to eliminate TRIMs by the year 2000. This is going to affect the local industry in the immediate run. For instance, the removal of local content requirements is going to hurt local industry, in particular the vendors. 
In future, while formulating domestic investment policies, Pakistan must ensure that its policies do not unduly prejudice the domestic industry as compared to foreign investors.

\section{TRIPs}

Pakistan is not a signatory to all the major international intellectual property right agreement, ${ }^{5}$ however, now it has committed to fulfil all WTO obligations. The major immediate challenge facing the country is to modify its existing intellectual property protection laws and to create an effective enforcement mechanism to ensure that intellectual property rights are truly protected.

With the implementation of the TRIPs agreement, it is expected that protected firms, especially in pharmaceutical products (medicine) and chemicals will choose to exercise their stronger rights in anti-competitive ways, raising prices and license fees and reducing our access to technology. Therefore, to the extent agricultural chemicals are subsidised, government will have to bear the additional burden of rising costs of these products. Pakistan will have to make more payments for royalty and technical fees, which will have balance of payment implications. Exports of counterfeit products will be no more possible. The Government will have to incur huge expenditure to enforce intellectual property laws.

The agreement is likely to restrict Pakistan's access to scientific and technological knowledge, which will have adverse implications for productivity growth in the country, and in turn for growth in real wages. Uncontrolled diffusion of intellectual property will not be possible under the new regime. Sweeping application of the WTO regime, even on small or simple processes, products, and technologies, which can be easily copied with indigenous resources, will certainly act as deterrent to technology transfer.

In future US Special 301 Procedure may counter Pakistan's infringement of intellectual property rights through such means as confiscation of counterfeit products and closure of production facilities involved in producing counterfeit products. ${ }^{6}$

Over the long run, Pakistan's strategic challenge is to promote indigenous technology by making greater investment in $R \& D$ and restructuring its ailing technology apparatus so as to minimise its dependence on foreign technology.

\section{Dumping Issues}

There is widespread belief in the international community that the most serious threat to global free trade has come from the increasing use (or misuse) of

${ }^{5}$ Pakistan is a signatory to Berne Convention on copyright, Universal Copyright Convention and World Intellectual Property Organisation (WIPO), but not a signatory to Paris Convention for the protection of industrial property.

${ }^{6}$ It may be noted that since 1996 Pakistan has been placed on the US Special 301 Watch List. It is suspected that the United States may elevate Pakistan to the Super Watch List. 
antidumping policy by the DCs. It is, therefore, feared that a further rise in antidumping actions would erode the entire liberalisation gains, which are expected from the Agreement.

So far the way the NTBs are used by the DCs strengthen the perception that these measures are used to provide a shield against competition from the LDCs. Likewise, arbitrary interpretation of the Rules of Origin and imposition of technical standards is threatening the trade-opening measures agreed in the Agreement. Moreover, to counter quota circumvention, such administrative procedures are adopted by the DCs, which are disrupting legitimate exports from LDCs.

The tariff and trade liberalisation in Pakistan has exposed a number of domestic producers to external competition. This is expected to bring an increased number of applications by Pakistani producers for anti-dumping or countervailing actions. This would require introduction of laws and their strict enforcement in the country.

\section{Eco-and Social-Dumping Issues}

The most serious external threat to Pakistan is now from the DCs' attempt to link their market access to performance in non-trade related areas such as the protection of environment and labour standards. The notion that a country with lower environmental or labour standards exporting its products to another with higher standards is engaged in eco-dumping and in unfair competition has gained ground among the DCs. Therefore, access to the markets of the DCs, particularly in labourintensive manufacture in which Pakistan has comparative advantage, is threatened by the DCs who are now insisting on setting and enforcing levels of labour or environment standards beyond Pakistan's stage of development. Pakistan has already expressed its concern at the application of trade legislation whose compatibility with the WTO Agreements is doubtful. ${ }^{7}$ Nevertheless, Pakistan will gradually improve environmental and labour standards, as it is committed to the observance of internationally recognised standards.

\section{A STRATEGIC DIRECTION}

For Pakistan the most important agenda for the WTO should be the effective implementation of the agreement and to ensure that it shares the maximum benefits from the new trade regime. Following actions can further strengthen the current initiatives taken by the government to meet the global challenges.

1. Government should prepare a plan to restructure the textile and clothing industry, of course, keeping an eye on the possibility of importing

${ }^{7}$ The WTO Ministerial Conference at Singapore in 1996 addressed the question of core labour standards and rejected the use of labour standards for protectionist purposes, while recognising that the comparative advantage of low-wage LDCs must not be put in jeopardy. Nevertheless, the LDCs fear that to restrict their exports the DCs will use other tactics such as anti-dumping measures. 
countries deviating from their ATC commitments. The government should administer MFA quota system through an allocation mechanism, which should aim at promoting value addition and quality.

2. The government efforts should be to ensure full utilisation of quota. A shortfall in quota utilisation will provide excuse to importing countries to delay their textile and clothing trade liberalisation.

3. Pakistan's multilateral trade negotiation agenda on textiles and clothing should also include that there is no linking of future integration programmes of the importing countries with any further market access on the part of the exporting countries.

4. Government should prepare a plan of productivity and efficiency improvement in each area so those domestic firms can effectively compete with foreign firms once the WTO agreements are fully implemented. This would require restructuring of Pakistan's ailing innovation system, provision of efficient soft and hard infrastructure, and development of skills. Furthermore, in order to gain a larger market share local producers/exporters should start observing internationally recognised quality standards in all field of economic activity.

5. Pakistan should take some credible measures by further liberalising economy and by modifying its laws on intellectual property protection, anti-dumping, countervailing and safeguard based on the principles of fair competition which should be clear, unambiguous and compatible with WTO agreements, and by adopting international enforcement procedures in order to give clear signals that it is committed to the preservation of a rule-based international trading system. In this way Pakistan can link additional and meaningful market access with its actions through bilateral negotiations.

6. It is worth noting that negotiators care only about the bound rate not the applied rate. Pakistan can draw considerable long-term benefits if its actions do not unnecessarily create the impression that it is not fully committed to a multilateral trading system.

7. Pakistan should actively participate in the future WTO negotiations so that its own agenda is ultimately incorporated into various agreements. In this regard, Pakistan can benefit by forging alliances with other countries having common interests.

\section{REFERENCES}

Azhar, R. A. (1995) The Uruguay Round and Pakistan's Exports. In The Implications of the Uruguay Round for Pakistan. Pakistan Institute of Development Economics, Islamabad. 
Bender, D. (1997) The Developing Countries in the New World Trade Organisation. Economics 55/56.

Falvey, R. E., and G. V. Reed (1998) Economic Effects of Rules of Origin. Weltwirtschaftliches Archiv 134:2.

Hoekman, B. (1995) Tentative First Steps: An Assessment of the Uruguay Round Agreement on Services. Paper presented at the World Bank Conference on the Uruguay Round and the Developing Economies, January 26-27.

Ingco, M. D., and L. A. Winters (1995) Pakistan and the Uruguay Round: Impact and Opportunities A Quantitative Assessment. A Background paper for Pakistan 2010 Report. International Economic Department, Trade Division. Washington, D.C.: The World Bank.

Jones, R. W. (1993) The New Protectionism and the Nature of World Trade. The Pakistan Development Review 32:4.

Khan, A. H., and Z. Mahmood (1996) Emerging Global Trading Environment: Challenges for Pakistan. Asian Development Review 14:2 73-115.

Low, P. (1995) Impact of the Uruguay Round on Asia: Trade in Services and TradeRelated Investment Measures. Paper presented at Conference on Emerging Global Trading Environment and Developing Asia. Asian Development Bank, Manila. 29-30 May.

Low, P., and A. Yeats (1994) Non-tariff Measures and Developing Countries: Has the Uruguay Round Levelled the Playing Field? The World Bank, Washington, D.C. (Policy Research Working Paper 1353.) 